Relations industrielles

Industrial Relations

\title{
New Catechism and Social Duties
}

Volume 7, numéro 1-2, décembre 1951, mars 1952

URI : https://id.erudit.org/iderudit/1023122ar

DOI : https://doi.org/10.7202/1023122ar

Aller au sommaire du numéro

Éditeur(s)

Département des relations industrielles de l’Université Laval

ISSN

0034-379X (imprimé)

1703-8138 (numérique)

Découvrir la revue

Citer ce document

(1951). New Catechism and Social Duties. Relations industrielles / Industrial

Relations, 7(1-2), 130-131. https://doi.org/10.7202/1023122ar

Tous droits réservés (C Département des relations industrielles de l’Université Laval, 1952
Ce document est protégé par la loi sur le droit d'auteur. L'utilisation des services d'Érudit (y compris la reproduction) est assujettie à sa politique d'utilisation que vous pouvez consulter en ligne.

https://apropos.erudit.org/fr/usagers/politique-dutilisation/ 


\section{NEW CATECHISM AND SOCIAL DUTIES}

A new edition of the Catholic catechism prepared by an episcopal commission formed in 1942 has just been published. It replaces the former one which has been in use for more than sixty years. The Archbishops of Quebec, Montreal, Ottawa, Rimouski and Sherbrooke have prescribed that it be taught in the schools under their jurisdiction.

In view of the ever-increasing social exigencies of the present-day world, a new section concerning the duties of employers and employees, citizens and those who govern, has been added to the lesson about the duties of inferiors and superiors.

Here is the text:

\section{Duties of Employees and Employers}

451-What does the fourth commandment of God command employees to do?

The fourth commandment of God commands employees to respect the person and the property of their employers, to work conscientiously and to observe their labour contract.

452-What does the fourth commandment of God command employers to do?

The fourth commandment of God commands employers to respect the person, the right of association and the labour contract of their employees, to pay them a family wage and to make it easy for them to accomplish their religious duties.

453-What must employees and employers do to settle their disputes?

They must use all honest and peaceful means at their disposition.

454-What is the best way to make sure that there is justice and charity between employees and employers?

To form Catholic associations or syndicates of employees and employers.

455-When do employees and employers have the right to suspend work to settle their disputes?

In extremely serious cases, after all other ways have been tried.

\section{Duties of Citizens and Those Who Govern}

456-What does the fourth commandment of God command citizens to do?

The fourth commandment of God commands citizens to love their native land, to work for its prosperity and to defend it even at the cost of their lives.

457-What must citizens do in order to work for the prosperity of their native land?

Respect the legitimate authority, obey just laws, choose conscientiously those who govern and accomplish their duties as citizens.

458-Why must we respect civil authority and obey the law?

Because all authority comes from God. 
459-How do citizens choose conscientiously those who govern?

In voting for the candidate that they judge to be the most capable of assuring the common good of all citizens.

460-What does the fourth commandment of God command those who govern to do?

The fourth commandment of God commands those who govern to assure the common good of all the citizens.

461-What is the common temporal good of all citizens?

It is the highest degree possible of well-being in this life, for the soul and the body, brought about by the union and cooperation of the efforts of all.

462-What must those who govern do to assure the common good of all the citizens? Respect the rights of all, make just laws, administer justice well, divide up equitably the tax burden, grants and public charges.

463-What are the rights that the State must respect?

The higher rights of God and the Catholic Church, the rights of the family and the human person, the rights of private associations and the rights of other countries.

\section{STATEMENT OF PRINCIPLES OF THE CCCL}

\section{Nature and Purpose}

The Canadian and Catholic Confederation of Labour is a free and democratic trade union organization. National in character, it derives inspiration for its principles and its activities from the social doctrine of the Church, which it recognizes as being the only doctrine capable of ensuring the social order.

Its purpose is to promote the professional, economic and moral interests of Canadian workers.

It aims at ensuring the individual and collective promotion of the workers by $\mathrm{fa}$ vouring their physical, intellectual and moral development and by creating for all conditions such as will enable them to live in a human and Christian way. It tries to contribute towards the establishment of orderly relations between employers and employees, in accordance with truth, justice and charity; among other immediate objectives in this domain, it aims at ensuring full use of the natural right of association and advocates collective agreements, social security measures and sound labour legislation.

\section{Professional Association}

The Syndicate is the most effective means the workers have of defending and pro- moting their professional interests. Therefore the natural right of association of all workers should be recognized, without distinction, and the putting into practice of this right should be facilitated, if necessary, by union security measures. The professional association is the worker's normal organization for bargaining, representation, participation and co-operation at all levels of the concern, of the profession and of the country's economy.

\section{Structure of the CCCL}

No workers' Syndicate may be admitted to membership in the CCCL unless it is first of all affiliated with its professional federation and with the central Council in its district or locality. Affiliation is not compulsory with any other labour organization set up by the affiliated bodies.

As long as its charter of affiliation is maintained, every affiliated body adheres to the present statement of principles and is bound to observe the rules and regulations of the CCCL.

\section{The Individual and the Common Good}

The economic system now prevailing in our country underrates human and spiritual values. According to this régime, the search 